Tür Turizm Araştırmalari Dergisi
2020,4(1): 426-446.
ISSN: $2587-0890$ Dergi web sayfasi: $\underline{\text { https://www.tutad.org }}$

\title{
Konaklama İşletmelerinin Yeni Hizmet Sunumunda Strateji Odaklılık Etkili Mi?*
}

Çağla YUMUK MERCAN, Yüksek Lisans Öğrencisi, Trakya Üniversitesi, Sosyal Bilimler Enstitüsü, Edirne, e-posta: caglayumuk061989@gmail.com

ORCID: https://orcid.org/0000-0002-1361-5173

Doç. Dr. Güney ÇETIN GÜRKAN, Trakya Üniversitesi, Uygulamalı Bilimler Yüksekokulu, Edirne, e-posta: guneycg@yahoo.com.tr ORCID: https://orcid.org/0000-0002-1964-6966

Doç. Dr. Gülsevim YUMUK GÜNAY, Trakya Üniversitesi, Uygulamalı Bilimler Yüksekokulu, Edirne, e-posta: gulsevimyumuk@gmail.com

ORCID: https://orcid.org/0000-0001-6184-0714

Öz

Günümüzde işletmeler için en önemli amaçlardan biri, sürdürülebilir bir rekabet gücüne sahip olmaktır. Konaklama işletmeleri için de iç ve dış çevre unsurlarını gözeterek sahip olunan strateji odaklı bakış açısının hizmet yeniliğine yönelik kararlarda etkili olabileceği düşünülmektedir. Bu bakış açısı ile çalışmada Trakya Bölgesi'nde yer alan konaklama işletmelerindeki 137 alt, orta ve üst kademe yöneticinin strateji odaklı bakışının yeni hizmet geliştirme kararlarındaki etkileri incelenmiştir. Çalışma kapsamında nicel araştırma yöntemlerinden yapılandırılmış anket tekniği kullanılmıştır. Anketler, istatistik paket programı ile analiz edilmiştir. Analiz tekniklerinden, spearman korelasyon analizi yanında, basit ve çoklu regresyon analizleri uygulanmıştır. Çalışma sonucunda konaklama işletmelerinin teknoloji ve pazar odaklılıktan oluşan strateji odaklı bakışının, yeni hizmet geliştirme ortamı ve yeni hizmet geliştirme desteği üzerinde olumlu ve anlamlı etkisi olduğu görülmüştür. Alt boyutlar bazında incelendiğinde ise, müşteri odaklılık ve fonksiyonlar arası koordinasyonun yeni hizmet geliştirmenin ortam ve destek boyutu üzerinde olumlu ve anlamlı etkisi görülürken, rakip odaklılığın herhangi bir etkisine rastlanmamıştır.

* Trakya Üniversitesi Sosyal Bilimler Enstitüsü Turizm İşletmeciliği ve Otelcilik ABD'da yazılmış yüksek lisans tezinin analizleri genişletilmiş versiyonudur.

Anahtar Kelimeler: Konaklama İşletmeleri, Strateji Odaklılık, Paar Odaklılık, Teknoloji Odaklılık, Yeni Hizmet Geliştirme.

Makale Gönderme Tarihi: 25.10.2019

Makale Kabul Tarihi: 08.01.2020

\section{Önerilen Atıf:}

Yumuk Mercan, Ç., Çetin Gürkan, G. ve Yumuk Günay, G. (2020). Konaklama İşletmelerinin Yeni Hizmet Sunumunda Strateji Odaklılık Etkili Mi?, Türk Turizm Araştırmaları Dergisi, 4(1): 426-446.

(C) 2020 Türk Turizm Araştırmaları Dergisi. 


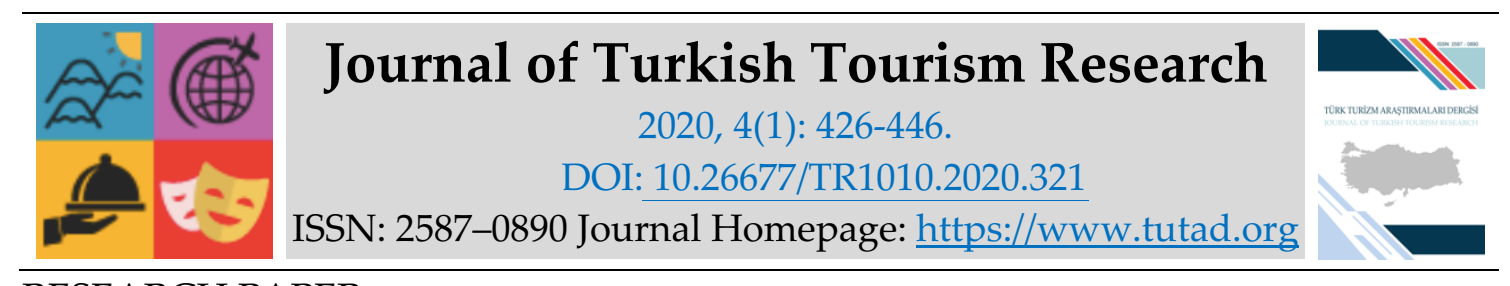

RESEARCH PAPER

\title{
Is Strategic Orientation Effective in the Development of New Services of Accommodation Businesses?
}

Çağla YUMUK MERCAN, MSc. Student, Trakya University, Social Sciences Institute, Edirne, e-mail: caglayumuk061989@gmail.com

ORCID: https://orcid.org/0000-0002-1361-5173

Associate Prof. Dr. Güney ÇETIN GÜRKAN, Trakya University, School of Applied Sciences, Edirne, e-mail: guneycg@yahoo.com.tr

ORCID: https://orcid.org/0000-0002-1964-6966

Associate Prof. Dr. Gülsevim YUMUK GÜNAY, Trakya University, School of Applied Sciences, Edirne, email: gulsevimyumuk@gmail.com

ORCID: https://orcid.org/0000-0001-6184-0714

\begin{abstract}
Nowadays, one of the most important objectives for businesses is to have a sustainable competitive power. It is considered that the strategy-oriented perspective, which can be developed by taking into account internal and external environmental elements, may be effective in the decisions regarding service innovation. From this point of view, the study examined the effects of the strategy-oriented views of 137 lower-, mid-, upper-level managers in accommodation businesses in the Thrace Region on the decisions of new service development. Structured questionnaire technique, which is one of the quantitative research methods, was used in the study. The questionnaires were analyzed with statistical package program. Spearman correlation analysis, simple and multiple regression analyzes were applied. As a result of the study, it was seen that the strategy-oriented views of accommodation businesses, which include technology and market orientation, had a positive and significant effect on new service development environment and new service development support. When examined in terms of sub-dimensions, customer orientation and inter-functional coordination had a positive and significant effect on the environment and support dimensions of new service development, but no effect of competitor orientation was found.
\end{abstract}

Keywords: Accommodation Businesses, Strategic Orientation, Market Orientation, Technology Orientation, New Service Development.

Received: 25.10 .2019

Accepted: 08.01.2020

\footnotetext{
Suggested Citation:

Yumuk Mercan, Ç., Çetin Gürkan, G. and Yumuk Günay, G. (2020). Is Strategic Orientation Effective in the Development of New Services of Accommodation Businesses?, Journal of Turkish Tourism Research, 4(1): 426-446.

(C) 2020 Türk Turizm Araştırmaları Dergisi.
} 


\section{Gíriş}

Küreselleşme ile birlikte tüketici yapısının hızlı bir şekilde değişmesi, işletmeleri de bulundukları pazarda değişikliklere daha duyarlı bir hale getirmiştir. Küreselleşmeden en çok etkilenen kurumların başında işletmelerin gelme sebebi, sürekli değişen müşteri istek ve ihtiyaçlarıdır. İşletmelerin üstün performans elde edebilmeleri için mevcut pazarı sürekli yakından takip etmeleri gerekmektedir. Bu doğrultuda strateji odaklı işletme yapısı ön plana çıkmaktadır.

Stratejik odaklılık ile pazar ve yenilik ayrımı üzerinde durularak üstün performans elde etmeye yönelik davranışlar (Zhou, Gao, Yang ve Zhou, 2005:1049) strateji, girişimcilik ve pazarlama ağırlıklı bakış açıları (Liu ve Revell, 2009) ile pazar, müşteri, maliyet, yenilikçilik, rakip, öğrenme, çalışan ve etkileşim (Grawe, Chen ve Daugherty, 2009) kavramları incelenmektedir. Sonuç olarak farklı araştırmacılar tarafından gerçekleştirilen farklı bakış açlarının ortak noktası, strateji odaklılığın nihai amaca ve üstün performans elde etmeye yönelik olarak gerçekleştirilmiş doğru uygulamaları kapsamış olmasıdır (Harsono ve Haryono, 2014:221). Strateji odaklılık, Pazar odaklılık ve teknoloji odaklılık olmak üzere iki boyutta incelenmektedir. Uzun dönemde karlılığ hedefleyen işletmelerin iç paydaşlarının (işletme sahiplerinin, yöneticilerin ve çalışanların) beklentilerini ihmal etmeden müşteri ilgisini ön planda tutan işletmeler olduğu görülmektedir. Bu bakış açısı ile Deshpande, Farley ve Webster (1993:25) pazar odaklılığı işletme kültürünün en temel öğesi olarak görmekte ve işletmenin müşterilerini her zaman ön planda tutmaları gerektiğini söylemektedir. Dolayısıyla yönetim sistemlerini oluşturan alt sistemlerin (örgütsel sistem, bilgi sistemi, planlama sistemi, denetim sistemi ve insan kaynakları sistemi) pazar odaklılık düzeyleri ile ayrı ayrı değerlendirilerek ele alınmasına ihtiyaç duyulmaktadır (Karamustafa, güllü, Acar ve Ulama, 2010:79). Strateji odaklılığın diğer boyutu olan teknoloji odaklılık ise, işletmenin teknoloji bilgi birikimini, kullanıcıların yeni ihtiyaçlarını karşılamak, yeni ürün/hizmet geliştirmek ve yeni bir teknik çözüm oluşturmak için kullanmasını ifade etmektedir.

Uluslararası düzeyde kabul edilen OECD Oslo kılavuzuna göre (2006:50); örgüt içinde gerçekleştirilen uygulamalarda, diş ilişkilerde yeni veya önemli derecede iyileştirilmiş ürün, mal veya süreçlerin yeni bir pazarlama yöntemi veya organizasyonel yönetim şeklinde ifade edilen yenilik kavramının strateji odaklılık ile ilişkisi olabileceği varsayılmaktadır (Liu ve Chen 2015; Zhou, Yim, Bennett ve Tse, 2005). Yenilik farklı sektörlerde olduğu gibi turizm sektöründeki konaklama işletmeleri için de oldukça önemlidir. Özellikle günümüz iş koşullarında işletmelerin ayakta kalabilmeleri için sürekli kendilerini yenilemeleri, pazardaki rakiplerini yakından takip etmeleri ve yeni hizmetler geliştirmeleri gerekmektedir. Sürekli değişen müşteri istek ve beklentileri karşısında konaklama işletmelerinin mevcut hizmetleri yetersiz kalabilmektedir. Dolayısıyla konaklama işletmelerinin pazarda ayakta kalabilmeleri için yenilikçi yönetim anlayışı ile hareket ederek işletmenin tamamında yeni hizmetler geliştirmelerine ihtiyaç duyulmaktadır.

Çalışmanın literatür kısmında; strateji odaklılık ve alt bileşenleri ile yenilik ve yeni hizmet geliştirme alt başlıklarından oluşturulmuştur. Strateji odaklılık ile yeni hizmet geliştirme arasındaki ilişkilere dayanılarak oluşturulan araştırma hipotezleri elde edilen veriler aracıllğ̆ ile test edilmiş ve yorumlanmıştır. 


\section{LITERATÜR TARAMASI Strateji Odaklılık}

Strateji odakl1lık, bir işletmenin büyümesine yol açan süreçleri, uygulamaları ve karar verme faaliyetlerini ifade eder. İşletmelerin stratejik karar süreçlerinin içine yerleşmiş olan örgütsel kalıpları, uygulama ve değerleri tanımlamak ve açıklamak amacıyla birçok yazar tarafından strateji odaklılık kavramı kullanılmaktadır (Escriba-Esteve, Sanchez-Peinado ve SanchezPeinado, 2009:583).

İlgili literatürde strateji odaklılık, pazar ve teknoloji odaklılık şeklinde iki bileşene ayırmıştır (Jaworski ve Kohli, 1993; Slater ve Narver, 1995; Atuahene-Gima ve Ko, 2001; Calantone, Chan ve Cui, 2006; Jeong, Pae ve Zhou, 2006; Tsou, Chen ve Liao, 2014; Lita, Meudhia ve Faisal, 2018). $\mathrm{Bu}$ ayırım, stratejik bakışın bir taraftan işletme dişındaki hedef pazarın tanınması ve beklentilerine cevap vermeyi gerektirirken, diğer taraftan da teknolojik anlamdaki gelişmelerin izlenmesi ve ayak uydurmasını gerektiğini göstermektedir.

Pazar odaklılık kavramının özellikle son yıllarda işletme ve pazarlama yazınında sık karşılaşılan kavramlardan olduğu görülmektedir. Kavramın özünü eldeki ürünü müşteri istek ve ihtiyaçlarına uygun hale getirmek oluşturmaktadır (Biçimveren, 2017:7). Yazında pazar odaklılık ile ilgili farklı bakış açılarına sahip yaklaşımlar bulunmaktadır. Shapiro (1988)'nun yaklaşımı, pazar odaklılığa sadece müşteriler ile yakın ilişki kurularak ulaşılamayacağını, müşterilerle kurulan ilişkilere dayanarak alınacak stratejik ve taktiksel kararların işletme bölümleri arasında koordineli bir şekilde yürütülmesine ihtiyaç olduğunu göstermektedir. Bu bağlamda, pazar odaklılık mevcut ve gelecekteki müşteri ihtiyaçlarının tespiti yanında, elde edilen verilerin bölümler arasında yaygınlaştırılması ve buna cevap verme istekliliği olarak (Kohli ve Jaworski, 1990:6) da düşünülmektedir. Stratejik bir perspektiften pazar odaklılık (Ruekert, 1992:228); a) iş biriminin müşterilerden bilgi toplaması ve kullanmasına, b) müşteri ihtiyaçlarına yönelik strateji geliştirmesine, c) geliştirilen bu stratejinin müşteri istek ve ihtiyaçlarının karşılanması için uygulamasına bağlıdır. Bu süreç içinde ilk adımı müşteri oluşturmaktadır. İkinci adım, müşteri odaklı stratejinin belirlenmesi ve son adım müşteri odaklı pazarın isteklerini örgütsel düzeyde duyarlılık gösterilerek geliştirilen müşteri odaklı stratejilerin uygulanmasıdır (Ayyıldız Ünnü, 2009:1250-1251).

Narver ve Slater (1990:23) ise, pazar odaklılığ1 "müşteri ve rakip bilgilerinin sürekli izlenerek, şirket içinde yayılması ve bu sayede şirketin bir bütün halinde çalışarak müşteriye değer yaratmasıdır" şeklinde tanımlamışlardır. Bu yaklaşım ile Narver ve Slater (1990:21) pazar odaklılığa; müşterileri, rakipleri ve işletme fonksiyonlarının bütünlüğünü dahil etmiştir. Dolayısıyla pazar odaklılık yapısının üç davranışsal bileşenden (müşteri odaklılık, rakip odaklılık ve fonksiyonlar arası koordinasyon) oluştuğunu ifade etmektedir. Müşteri odaklılık, hedef müşterilerin daha iyi anlaşılmasını ifade ederken, müşterilere üstün bir değer de kazandırmaktadır. Bazı araştırmacılara göre (Slater ve Narver, 1994; Deshpande vd., 1993; Deng ve Dart, 1994) müşteri odaklılığın, pazar odaklılığın kalbi olduğu ve müşteri odaklılığa dayalı işletme felsefesinin işletmenin genelinde uygulanması gerektiği ifade edilmektedir. Bu uygulama hedefteki müşterilerin ihtiyaçlarının anlaşılmasını (Naktiyok, 2003:97), satış sonrası müşterilerden gelen istek ve şikayetlerin dinlenmesini (Gray, Matear, Boshoff ve Matheson, 1998) ve bu doğrultuda ürün/hizmet yaratma yöntemlerinin araştırılarak müşteri tatmininin sürekli ölçülmesini müşteri odaklılık için gerekli kılmaktadır (Akman, Özkan ve Eriş, 2008:95). Rakip odakllık ile işletmenin pazardaki mevcut ve potansiyel rakiplerinin faaliyetlerini izleme, ürünleri ve hizmetleri hakkında bilgi edinme, gelecekteki faaliyetlerini anlama ve uygun cevapları 
verebilmesine yönelik süreçler anlaşılmaktadır (Narver ve Slater, 1990; Kohli ve Jaworski, 1990). $\mathrm{Bu}$ süreç içinde kısa dönemde mevcut rakiplerin güçlü ve zayıf yönleri hakkında bilgi toplanması, orta vadede potansiyel rakiplerin kimler olacağının tespiti (Bulut, Alpkan ve Yılmaz., 2009:520), uzun vadede ise mevcut ve potansiyel rakiplerin yeteneklerinin ve stratejilerinin anlaşılması hedeflenmektedir (Narver ve Slater, 1990:21). Fonksiyonlar arası koordinasyon ise, hedef müşteriler için üstün değer yaratmada işletme kaynaklarının koordineli bir şekilde kullanımını ifade etmektedir. Müşteriler için üstün değer yaratmak için işletmenin tüm bölümleri ile bütünleşmesine, gerektiğinde tüm insani ve diğer sermaye kaynaklarının uyarlanmasına ihtiyaç duyulmaktadır (Narver ve Slater, 1990:22).

Teknoloji odaklılık kavramı, işletmelerin teknolojik gelişmeleri yakından takip etmesi, teknolojik fırsatları rakiplerinden önce algılayabilmesi, işletmelerin yenilikçi kabiliyetlerini geliştirmesi olarak tanımlamaktadır (Akman ve Yılmaz, 2008:84).

Tek boyutlu bir yapı olarak düşünülen teknoloji odaklılık yaklaşımı fonksiyonel düzeyde analiz edilmeye (Bulut vd., 2009:27) çalışılmış ve kültürel temelli bir kurumsal/iş birimi seviyesinde güçlü bir AR-Ge ve ileri teknoloji alt yapısı ile sınırlandırılmıştır (Halaç, 2014:49). Oysaki teknoloji odaklılık, işletmenin teknolojiyi başlatma, takip etme, uyarlama, geliştirme ve kullanma konusundaki istekliliğini göstermektedir (Karabulut, 2015: 5). Halaç (2014:46) teknoloji odaklılığın kendinden beklenilenlere cevap verebilmesi için tepe yönetimin kabiliyeti, teknoloji kabiliyeti, öğrenmeye bağlllık ve değişime bağhllık olmak üzere dört bileşene ayırarak incelemiştir. Tepe yönetim kabiliyeti, işletmelerin mevcut operasyonlarını güncel teknolojilerle yürütmesi veya Ar-Ge yatırımlarına öncelik vererek ileri ve yüksek teknolojiye odaklı bakış açısına sahip olmak olup yöneticilerin sorumluluğunda bulunmaktadır. Tepe yönetimin bu bağlamda dışarıdan teknoloji geliştirip geliştirmeyeceğine, Ar-Ge'ye ne ölçüde yatırım yapılacağına ve rakipleri ile ne ölçüde rekabet veya işbirliği yapacağına dair gerekli kabiliyete sahip olması gerekmektedir (Halaç, 2015:1058). Teknoloji kabiliyeti ise, çeşitli teknolojik faaliyetler yoluyla işletmenin performansına yansıyan ve kopyalanması zor organizasyon becerilerini geliştiren ve nihai amacı firma seviyesinde değer yönetimi olan fonksiyonel yeteneklerdir (Panda ve Ramanathan, 1996:562) İşletmelerin teknoloji kaynakları sahip oldukları rekabet avantajlarının merkezinde yer almaktadır. Bunun sebebi işletmelerin rakiplerinin teknolojik kaynak tahsislerinden ve bunların performansa nasıl katkıda bulunduğundan habersiz olmaları ve bu teknolojik kabiliyetleri zor taklit etmeleridir. Öğrenmeye bağgllık, örgütsel öğrenmeyi daha iyi örgütsel performansa katkıda bulunacak olan kaynakların ve yeteneklerin geliştirilmesine yönelik bilginin yaratılması, edinilmesi ve bütünleştirilmesi sürecidir (Lopez, Peon ve Ordas, 2005:228). Değişime bağlllık ise, bilginin kaldırılması/atılması ile ilgili olabilir aynı zamanda ilgisiz eskimiş gibi öznel bir değere sahip olabilir ya da kendi başına bir son veya sona ulaşmak için bir araç olarak kullanılabilir (Srithika ve Bhattacharyya, 2009:69). Bu sebeple, yeni öğrenmeyi kolaylaştıran temel bir süreçtir. Çünkü kurumun hafızasında, kültüründe ve rutinlerinde var olan dogmaları ve prosedürleri ortadan kaldırarak yeni öğrenimler için yer açmaktadır (Halaç, 2015: 1059).

\section{Yeni Hizmet Geliştirme}

Yenilik, Latince "innovatus" kelimesinden türemiş olup; yeni bir şey yapma, anlamına gelmektedir. Türkçe kullanımı konusunda fikir birliğine tam olarak varılmamış olsa da bazıları bu kavramın İngilizce karşılığı "innovation" yani inovasyon olarak kullanılması gerektiği görüşündedir. Türk Dil Kurumunun bu konuyla ilgili yaptığı çalışma sonucunda ise inovasyon kelimesinin karşılığı olarak "yenileşme" kelimesinin kullanılması önerilmiştir. Kavramın 
içeriğini tam olarak yansıtmamakla birlikte en yakın anlamı olarak "yenilik" kelimesi alan yazında en sık rastlanılan kelimedir (Gökçek, 2007:4).

Yenilik bir işletmenin iş yapış yöntemlerinde, tasarım ve pazarlama yöntemlerinde, üretim dağıtım yöntemlerinde, ürünlerinde ve hizmetlerinde yapılabilir. Bunlarda sırasıyla, "örgütsel yenilik", "pazarlama yeniliği", "süreç yeniliği", "ürün yeniliği", "hizmet yeniliği" olarak adlandırılır (Elçi, 2007:3).

Örgütsel Yenilik: Örgütsel yenilik bir işletmenin ticari uygulamalarında, işyeri örgütünde veya dış ilişkilerinde yeni, farklı ve değişik bir örgütsel yöntemin uygulanması olarak ifade edilmektedir (Adıgüzel, 2012:38). Yeni iş yapma ve çalışma yöntemlerinin geliştirilerek veya var olan yöntemlerin işletme şartlarına uyarlanarak kullanılması örgütsel yenilik olarak ifade edilmektedir (Elçi, 2007:10).

Pazarlama Yeniliği: Polder, Leeuwen, Mohnen ve Raymond (2010:2) pazarlama yeniliğinin teknolojik olmayan bir yenilik olduğuna inanmakta ve işletmelerin verimliliğini arttırmak için pazarlama yöntemlerinde yenilik yaptıklarını ileri sürmektedir. İşletme pazarlama yeniliğinde, pazar payını arttırarak rakiplerine karşı rekabet avantajı elde edebilecek ya da mevcut durumunu koruyarak karlılığını arttırabilecektir (Çınar, 2017:40).

Süreç Yeniliği: Durna (2002:67), süreç yeniliğini bir ürünün yapımı veya hizmetin sunumu sırasında yapılan değişiklikleri kastetmektedir. Kullanıcılar tarafından ürünün kalitesi veya maliyetindeki değişimler dışındaki süreç yenilikleri görülmeyebilir. Dolayısıyla süreç yeniliği ile hizmetin yaratılması ve tedarikine ilişkin yeni veya önemli derecede iyileştirilmiş yöntemler kullanılabilmekte (Oslo Kılavuzu, 2005:53) ancak bu yenilikler kullanıcıların dikkatini çekmemektedir. Oysaki süreç yeniliğine yönelik gerçekleştirilen bu uygulamalar üretimde verimlilik artışı ve maliyet tasarrufu gibi katkılar sağlayabilmektedir (Akgemci ve Güleş, 2010:141).

Ürün Yeniliği: Ürün yeniliği, dış pazar veya kullanıcı ihtiyacını karşılamak için yeni ürün tanıtımına işaret etmektedir (Damanpour, 1996:698). Aynı zamanda, ürün yeniliği mevcut pazarlar/müşteriler yaratmak veya mevcut pazarların/müşterilerin beklentilerine cevap vermek için yeni ürün ve ürüne ait hizmetlerin üretimi ile de ilgilenmektedir (Wan, Ong ve Francis, 2005:262).

Hizmet Yeniliği: Hizmet yeniliği; müşteriler, işletmeler, şirket ortakları ve genel olarak toplum için değerler oluşturmak üzere yenilikçi hizmetler, hizmet süreçleri ve hizmet modelleri yaratmak için yeni veya geliştirilmiş yöntemlerin kullanılmasıdır (Ostrom, Bitner, Brown, Burkhard, Goul, Smith-Daniels, Demirkan ve Rabivich, 2010:5). Avlonitis, Papastathopoulou ve Gounaris (2001:487)'ne göre, hizmet yeniliği tamamen yeni bir hizmete işaret etmektedir. İşletmeler için bu durum, yeni hizmet süreçlerini, uygun hizmet iyileştirmelerini, hizmet durumunun genişletilmesini ve hizmetlerin yeniden konumlandırılmasını da içerir. Vang ve Zellner (2005:147) hizmet yeniliğini, işletmelerin müşterilerinin farklı ihtiyaçlarını karşılamak için ürün veya hizmet değerini yükseltmek amacı ile bir iyileştirme önlemi olarak görmektedir. Cheng ve Krumwiede (2012) hizmet yeniliğinin, yüksek değerli hizmet yaratmanın müşteri ihtiyaçlarının karşılanması ve iş performansını iyileştireceği görüşündedir.

Yeni hizmet geliştirme ise, ilk fikirden yeni hizmetlerin son aşamasına kadar geçen sürede gerçekleşen faaliyetler dizisi olarak ifade edilmektedir. Aynı zamanda yeni ürün geliştirme; 
pazar fırsatları ve müşteri istekleri hakkında bilgi girdisinin dönüşüm süreci olarak tanımlanmaktadır. Bu bakımdan, yeni hizmet geliştirme son zamanlarda büyük pazar payı elde etmek için rekabetçi bir rol oynamaktadır (Lu ve Gama, 2007:1423, Akt., Dinçer, 2010:93).

Avlonitis vd., (2001:326) yeni hizmet geliştirme ile ilgili süreçleri 5 grupta değerlendirmektedir:

- Fikirlerin Oluşturulması ve Elenmesi: Alternatif fikirler incelendikten ve belirli pazar temelli ve teknik kriterlere göre değerlendirildikten sonra uygun olanlar seçilerek diğerleri elenir.

- Isş Analizi ve Sonrasında Pazarlama Stratejilerinin Belirlenmesi: Pazar koşullarının, tüketici eğilimlerinin, müşteri ihtiyaçlarının ve yeni teklifin geliştirilmesi ve teşvik edilmesi için gerekli yatırımların analizine dayanan yeni girişimlerin fayda maliyet analizinin yapıldığı aşamadır.

- Teknik Gelişim Aşaması: Yeni hizmet ile ilgili süreç prosedürlerinin ve sistem tasarımının geliştirildiği aşamadır.

- Test Aşaması: Yeni hizmetin uygulanabilir olup olmadığını, hizmetin geliştirildiği organizasyon içinde ya da hedef pazarda testlerin yapıldığı aşamadır.

- Yeni Hizmetin Ticarileştirilmesi: Hizmetin pazara girişini ve performansının değerlendirilmesini ifade eden hizmetin ticarileştirilmesi / lansmanı ve pazara sürülme aşamasıdır.

Yeni hizmet geliştirmenin işletmelere sağladığı faydaların başında ürünlerin karlılığını arttırma, yeni müşterileri cezbetme, pazarda fırsatlar yaratma ve mevcut müşteri sadakatini arttırma yer almaktadır (Storey ve Easingwood, 1999; Akt., Dinçer, 2010:91).

\section{STRATEJİ ODAKLILIK VE YENI HIZZMET GELIŞTIRME İLIŞKİSI}

Strateji odaklılık, işletmenin stratejik seçimler ve çevre ile arasındaki uyumun dışa dönük bir görünümünü yansıtmaktadır. Stratejik bir seçim olan strateji odaklılık işletmelerin dinamik yetenekler yaratmak için kaynak edinme, tahsis etme ve kullanma yöntemlerini belirlerken aynı zamanda dış çevre (müşteri, rakip ve teknoloji) ile nasıl etkileşimde olduğuna da odaklanmaktadır (Zhou ve Li, 2010:224). İşletmelerin küresel pazarda hayatta kalabilmeleri ve rekabet avantajı kazanmaları için "yenilik" stratejik bir araç olarak kullanılmaktadır. Çünkü yenilikçi yaklaşımlar ile işletmeler performanslarını artırabilmekte, rakiplerinin önüne geçebilmekte ve paydaşlarına değer yaratabilmektedir (Karabulut, 2015:1355). Yenilikçi işletmelerin bu uygulamaları ülke ekonomilerini hizmet üretimine yöneltmiş (Ottenbacher ve Harrington, 2010:3) ve özellikle de yeni hizmet gelişimindeki çabalar konumsal avantaja sahip olunmasını sağlamıştır (Matear, Gray ve Garrett., 2003:288).

Geçmişte yapılan çalışmalar (Liu ve Chen 2015; Zhou vd.2005) strateji odaklı bakış açısının yenilik ile ilişki içinde olduğunu belirtirken, strateji odaklılığın hizmet yeniliği üzerinde olumlu bir etkiye sahip olduğunu ortaya koymaktadır. İşletmeler strateji odaklılığın en fazla pazar odaklılık boyutunu ele almaktadır. Bu bağlamda gerçekleştirilen çalışmalarda, pazar odaklılık ve yeni hizmet geliştirme arasındaki olumlu ilişkinin varlığ1 (Atuahane-Gima 1995:275; Lado ve Maydeu-Olivares 1998:1) yanında pazar odaklılı̆̆ın en önemli göstergesinin yenilik başarısı olduğu (Deshpande vd., 1993: 31) görülmektedir. Lado ve Maydeu- Olivares (1998) da pazar odaklı firmaların daha yüksek yenilik başarısına sahip olduklarını ifade etmektedir. Grawe vd., (2009:282) pazar odaklılığın iki alt boyutu olan rakip odaklılık ve müşteri odaklılık ile hizmet yeniliği arasında olumlu ilişki tespit etmiştir. Ho, Nguyen, Adhikari, Miles ve Bonney, (2018:154) de pazar odaklılığın üçüncü boyutu olan fonksiyonlar arası koordinasyonun yenilik ile olumlu ilişkisinden bahsetmektedir. Strateji odaklılığın pazarlama boyutu dışındaki diğer boyutu 
teknoloji odaklılığın da teknoloji tabanlı yenilikler ve performans üzerinde etkili olduğu (Zhou vd., 2005) bilinmektedir. Söz konusu çalışmalar 1şı̆̆ında, strateji odaklılığın yeni hizmet geliştirme üzerinde etkili olabileceği varsayımından hareketle, Türkiye'deki konaklama işletmelerinde de yeni hizmet geliştirme potansiyelini strateji odaklılığın etkileyip etkilemediğini ortaya koymak amacıyla aşağıdaki hipotezler oluşturulmuştur.

Araştırmanın Hipotezleri:

1H1: Strateji odaklılığın yeni hizmet geliştirme üzerinde anlamlı etkisi vardır.

$2 \mathrm{H}_{1}$ : Pazar odaklılığın yeni hizmet geliştirme üzerinde anlamlı etkisi vardır.

2HıA: Müşteri odaklılığın yeni hizmet geliştirme üzerinde anlamlı etkisi vardır.

2Н1в:Rakip odaklılığın yeni hizmet geliştirme üzerinde anlamlı etkisi vardır.

2H1c: Fonksiyonlar arası koordinasyonun yeni hizmet geliştirme üzerinde anlamlı etkisi vardır.

$3 \mathrm{H}_{1}$ :Teknoloji odaklılığın yeni hizmet geliştirme üzerinde anlamlı etkisi vardır.

\section{METODOLOJI}

\section{Araştırmanın Amacı ve Önemi}

Varlığını uzun süre devam ettirmek ve rekabet üstünlüğü yaratmak isteyen konaklama işletmelerinin strateji odaklı (pazar odaklılık ve teknoloji odaklılık) hareket etmeleri yanında yeniliğe karşı tutumları önemlidir. Bu bağlamda konaklama işletmelerinin strateji odaklı bakış açısının (alt boyutları ile) yeni hizmet geliştirme faaliyetleri üzerindeki etkisinin ortaya konması çalışmanın amacını oluşturmaktadır. Türkiye'de strateji odaklılık bakış açısını konaklama işletmeleri örnekleminde inceleyen sadece birkaç çalışma (Agarwall,Erramilli ve Dev, 2003; Küçük ve Kocaman, 2014; Çınar, 2017) olmakla birlikte strateji odaklılık ile yeni hizmet geliştirme kavramlarını ele alan her hangi bir çalışmaya rastlanmamaktadır. Dolayısıyla konaklama işletmelerindeki strateji odaklılık bakış açısının özellikle yeni hizmet geliştirilmesi ile olan ilişkisinin ortaya konmasının hem ilgili literatür hem de konaklama sektörü açısından önemli olduğu düşünülmektedir.

\section{Veri Toplama Yöntemi}

Araştırmada veriler anket tekniği ile toplanmıştır. Kullanılan anket formu dört bölümden oluşmaktadır. Anket formunun birinci bölümünde Narver ve Slater (1990) tarafından geliştirilen ve Türkçeye Atilla Sürer (2012) tarafında uyarlanan "Pazar Odaklılık Ölçeği" kullanılmıştır. Pazar odaklılık ölçeği üç boyuttan (müşteri odaklılık, rakip odaklılık ve fonksiyonlar arası koordinasyon) oluşmaktadır. Anket formunun ikinci bölümünde tek boyutlu olan "Teknoloji Odaklılık Ölçeği" yer almakta olup ölçek, Gatignon ve Xuereb (1997) tarafından geliştirilmiş ve Türkçe'ye Atilla Sürer (2012) tarafından uyarlanmıştır. Üçüncü bölümdeki "Yeni Hizmet Geliştirme Ölçeği" ise Hu, Horng ve Sun (2009) tarafından geliştirilen, Işık (2018) tarafından geçerlilik ve güvenilirliği yapılan tek boyuttan oluşmaktadır. Anket formunun dördüncü ve son bölümü demografik faktörlere ait yedi adet soruyu içermektedir. Anket formunun ilk üç bölümündeki ölçekler de yer alan önermeler beşli Likert tipinde ve " $1=$ Kesinlikle katılmıyorum" ile " $5=$ Tamamen katılıyorum" arasında derecelendirilerek değerlendirilmiştir.

\section{Evren ve Örneklem}

Araştırmanın evreni, Trakya Bölgesi'nde hizmet veren turizm belgeli konaklama işletmelerinde çalışan yöneticilerdir. İl Kültür ve Turizm Müdürlüklerinin resmi web sitelerindeki verilere göre Edirne, Tekirdağ ve Kırklareli ilinde 62 turizm belgeli konaklama işletmesi olduğu tespit edilmiştir. Katılımcılar Trakya Bölgesi'ndeki konaklama işletmelerinde aktif olarak çalışmakta olan alt, orta ve üst kademe yöneticilerdir. Trakya Bölgesi'nde bulunan 62 konaklama işletmesinin her birinde strateji ile ilgili bilgi sahibi olduğu öngörülen 3 yönetici olduğu 
varsayımından hareketle 186 yönetici ana kütle olarak belirlenmiştir. \%95 güven aralığ $\% 5$ hata payı ile öngörülen örnek büyüklüğü minimum 126 olarak tespit edilmiştir. Çalışma yüz yüze gerçekleştirilen anket tekniği ile 13.09.2018/30.09.2018 tarihleri arasında gerçekleştirilmiştir. Çalışmaya 142 adet yönetici katılmıştır. Katılımcılardan alınan beş adet anketin eksik ve hatalı doldurulmuş olması sebebiyle bu anketler analizlerden çıkartılmış ve çalışma 137 adet katılımcıya ait anket ile gerçekleştirilmiştir.

\section{Araştırmanın Modeli}

Çalışmanın amacına yönelik olarak hazırlanan anket formundaki sorular aracılığı ile ölçülmeye çalışılan ifadeler çerçevesinde hazırlanan model aşağıda yer almaktadır.

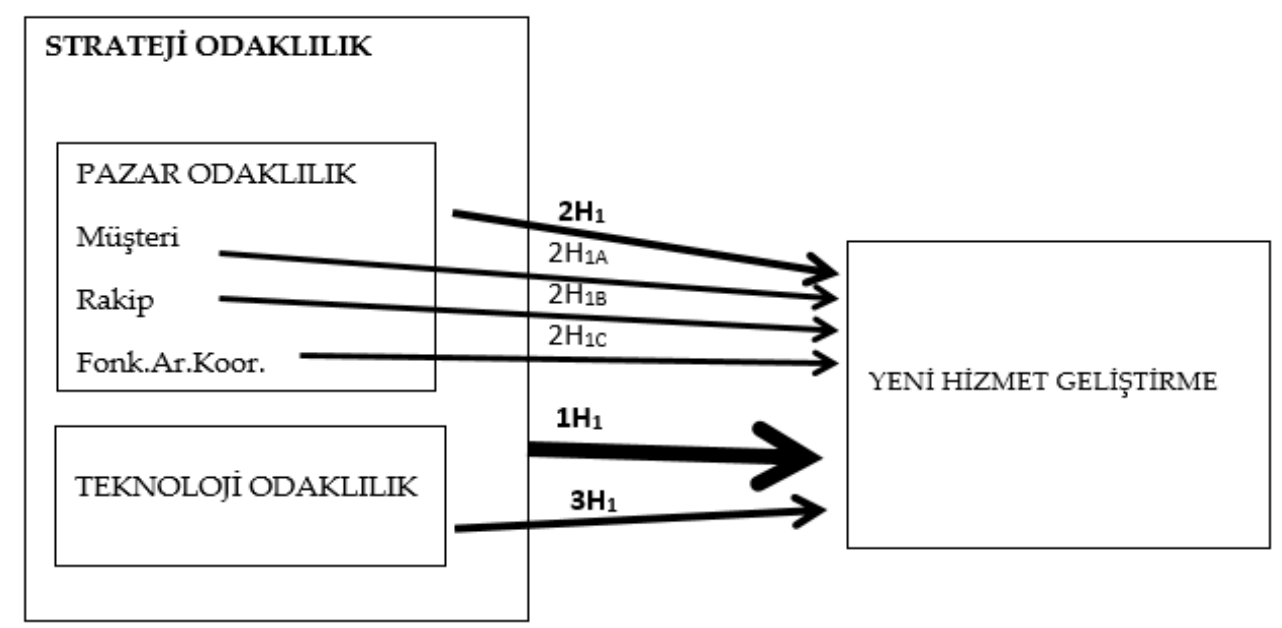

Şekil 1. Araştırmanın Modeli

\section{ARAŞTIRMA BULGULARI \\ Kullanılan Ölçeklerin Geçerlilik ve Güvenilirlikleri ile Faktör Analizi Sonuçları}

Güvenilirlik analizi için Cronbach Alfa Katsayısı yöntemi kullanılmıştır. Pazar odaklılık ölçeğinin güvenilirliği 0,738 , teknoloji odaklılık ölçeğinin güvenilirliği 0,886 ve yeni hizmet geliştirme ölçeğinin ise $0,865^{\prime}$ dir. Sonuç olarak katılımcılara uygulanan ve toplamda 29 maddeden oluşan araştırma ölçeğinin Cronbach Alfa değeri 0,884 olup yüksek derecede güvenilir bir ölçek olduğu görülmektedir.

Pazar odaklılık için KMO ölçütü 0,727 olarak hesaplanmıştır. Pazar odaklılığın Bartlett test sonuçları $(\chi 2=810,481 ; \mathrm{df}=105, \mathrm{p}=0,000 ; \mathrm{p}<0,05)^{\prime}$ nın anlamlı olduğu ve değişkenler arasında yüksek korelasyonların mevcut olduğu anlaşılmaktadır. Buna göre; veri seti faktör analizi için uygun olarak değerlendirilmiştir. Pazar odaklılığa ait ölçüm aracı için dik döndürme yöntemi olan Varimax kullanılmış ve 7 nolu maddenin düşük değere sahip olması ve iki farklı boyutta düşük faktör yükü ile yer alması nedeniyle analizden çıkartılmıştır. Geri kalan 15 maddenin varyansa yaptıkları toplam katkı ise \%58,117' dir. Teknoloji odaklılığa ait ölçüm aracına ait KMO ölçütü 0,861 olarak hesaplanmıştır. Teknoloji odaklılığın Bartlett test sonuçları ( $\chi 2=400,350 ; \mathrm{df}=10$, $\mathrm{p}=0,000 ; \mathrm{p}<0,05)^{\prime}$ nın anlamlı olduğu ve değişkenler arasında yüksek korelasyonların mevcut olduğu anlaşılmaktadır. Faktörleştirme sonucunda 5 maddeden oluşan ölçüm aracında faktör yük değeri düşük ve binişik madde bulunmamaktadır. Literatüre uygun olarak tek boyut altında toplanan maddelerin varyansa yaptıkları toplam katkı \%70,132'dir. Yeni hizmet geliştirmenin 
KMO ölçütü 0,859 olarak hesaplanmıştır. Bartlett test sonuçları ise $(\chi 2=476,225 ; \mathrm{df}=28, \mathrm{p}=0,000$; $\mathrm{p}<0,05)^{\prime}$ nın anlamlı olduğu anlaşılmaktadır. Yeni hizmet geliştirme ölçeğinin faktörleştirme sonucunda 8 maddeden oluşan ölçüm aracında faktör yük değeri düşük ve binişik madde bulunmamakla birlikte, orijinal ölçekten farklı olarak iki ayrı boyutta dağılım gösterdiği görülmüştür. Söz konusu maddelerin içeriği incelendiğinde, bu iki boyuttan ilkinin yeni hizmet geliştirilmesindeki çalışma ortamına ilişkin maddeleri, diğer boyutunun ise işletme ve yönetici tarafından çalışana sunulan fırsat yani desteklere ilişkin maddeleri kapsadığı görülmüştür. Dolayısıyla ilk boyut, "Yeni Hizmet Geliştirme ORTAM" ve ikinci boyut ise "Yeni Hizmet Geliştirme DESTEK" boyutları olarak adlandırılmıştır.

Yeni hizmet geliştirme ölçeğinin iki alt boyuta ayrılması sebebiyle ana hipotez sabit kalmak kaydıyla, mevcut hipotezlerimiz revize edilerek yeni hipotezler ile çalışma detaylandırılmıştır.

$1 \mathrm{H}_{1}$ : Strateji odaklılığın yeni hizmet geliştirme üzerinde anlamlı etkisi vardır.

1H1a: Strateji odaklılığın alt boyutlarının yeni hizmet geliştirme ortamı üzerinde anlamlı etkisi vardir.

1Hı: Strateji odaklılığın alt boyutlarının yeni hizmet geliştirme desteği üzerinde anlamlı etkisi vardir.

2H1Aa: Müşteri odaklılığın yeni hizmet geliştirme ortamı üzerinde anlamlı etkisi vardır.

$2 \mathrm{H}_{1 \mathrm{Ab}}$ : Müşteri odaklılığın yeni hizmet geliştirme desteği üzerinde anlamlı etkisi vardır.

2Hıв:Rakip odaklılığın yeni hizmet geliştirme desteği üzerinde anlamlı etkisi vardır.

$2 \mathrm{H}_{1 \mathrm{Ca}}$ : Fonksiyonlar arası koordinasyonun yeni hizmet geliştirme ortamı üzerinde anlamlı etkisi vardir.

2Hıcb: Fonksiyonlar arası koordinasyonun yeni hizmet geliştirme desteği üzerinde anlamlı etkisi vardir.

\section{Demografik Özellikler}

Araştırmaya katkı gösterenlerin \% 69,3 oranında erkek çalışanların oluşturduğu ve \% 30,7 gibi daha düşük bir oranda da kadın çalışanlardan oluştuğu görülmektedir. Katılımcıların \%28,5 oranında 21-30 yaş aralığında, \%35 oranında 31- 40 yaş aralığında, \%19,7 oranında 41-50 yaş aralığında, \%11,7 oranında 51-60 yaş aralığında ve \%5,1 oranında 61 yaş ve üstü oldukları görülmektedir. Katılımcıların \%62'si evli, \%38'i bekar olduğu görülmektedir. Katılımcıların yaklaşık \% 60'ının üniversite eğitimi aldığı ve yaklaşık \% 75'inin orta düzey yönetici olduğu görülmektedir. Katılımcıların bu meslekteki çalışma yılları değerlendirildiğinde \% 11,7'si 1-5 yıl arasında, \% 28,5'si 6-10 yıl arasında, \% 21,9'u 11-15 yıl arasında, \% 15,3'ü 16-20 yıl arasında ve \% 22,6'sı 20 yıl ve üzeri süredir bu meslekte görev yapmaktadır. Katılımciların \% 38,7'si 1-5 yıl arasında bu konaklama işletmesinde görev yapmakta iken, \% 24,8'i 6-10 yıl arasında, \% 18,2'si 11-15 yıl arasında, \% 7,3'ü 16-20 yıl arasında ve \% 10,9'u 20 yıl ve üzeri süredir kurum bünyesinde görev yapmaktadır. Trakya Bölgesi'ndeki konaklama işletmelerinde çalışan yöneticilerin büyük bir kısmını erkek yöneticilerin oluşturduğu, yöneticilerin yarıdan fazlasının üniversite mezunu olduğu görülmüştür. Ayrıca, orta kademe yöneticilerin diğer yöneticilere nazaran oldukça yüksek sayıda olduğu göze çarpmaktadır. Araştırmaya katılan yöneticilerin yaklaşık \%64'ünün 40 yaş ve altında oldukları, yani gençlerin yönetici pozisyonlarında kendilerine kariyer imkanı buldukları gözlenmiştir. Fakat mevcut işletmelerinde yönetici olarak uzun yıllardır çalışmadıkları da (yaklaşık \%64'ü 10 yıl ve altı) tespit edilmiştir.

\section{Korelasyon Analizi}

Veriler normal dağılım göstermediği için Spearman korelasyon analizi yapılmış ve Tablo 1'de görüldüğü gibi strateji odaklılık, pazar odaklılık ve pazar odaklılığın alt boyutları (müşteri, rakip ve fonksiyonlar arası koordinasyon), teknoloji odaklılık, yeni hizmet geliştirme ve yeni hizmet 
geliştirmenin alt boyutları (ortam ve destek) arasında olumlu yönlü ve anlamlı ilişkiler tespit edilmiştir.

Tablo 1. Strateji Odaklılık ve Alt Boyutları ile Yeni Hizmet Geliştirme ve Alt Boyutları Arasındaki İlişkiler

\begin{tabular}{|c|c|c|c|c|c|c|c|c|c|c|c|c|}
\hline & Değişkenler & Ort. & Ss. & 1 & 2 & 3 & 4 & 5 & 6 & 7 & 8 & 9 \\
\hline 1 & $\begin{array}{l}\text { Strateji } \\
\text { Odakl1lık }\end{array}$ & 3,998 & 0,554 & 1 & & & & & & & & \\
\hline 2 & $\begin{array}{l}\text { Pazar } \\
\text { Odaklılık }\end{array}$ & 4,139 & 0,466 & $\begin{array}{l}, 764^{+} \\
+\end{array}$ & 1 & & & & & & & \\
\hline 3 & $\begin{array}{l}\text { Müşteri } \\
\text { Odaklılık }\end{array}$ & 4,547 & 0,444 & $\begin{array}{l}, 529^{+} \\
+\quad \\
\end{array}$ & ,594++ & 1 & & & & & & \\
\hline 4 & $\begin{array}{l}\text { Rakip } \\
\text { Odaklılık }\end{array}$ & 3,476 & 1,120 & $\begin{array}{l}, 426^{+} \\
+\end{array}$ & 699++ & 106 & 1 & & & & & \\
\hline 5 & $\begin{array}{l}\text { Fonksiyonlar } \\
\text { Arası } \\
\text { Koordinasyon }\end{array}$ & 4,179 & 0,687 & $\begin{array}{l}\text {,624+ } \\
+\end{array}$ & $672^{++}$ & $474^{++}$ & ,081 & 1 & & & & \\
\hline 6 & $\begin{array}{l}\text { Teknoloji } \\
\text { Odaklılık }\end{array}$ & 3,856 & 0,833 & $\begin{array}{l}\text {,917+ } \\
+\quad\end{array}$ & $485^{++}$ & $406^{++}$ & $\begin{array}{l}\text {,181 } \\
+\end{array}$ & $\begin{array}{l}454 \\
++\end{array}$ & 1 & & & \\
\hline 7 & $\begin{array}{l}\text { Yeni Hizmet } \\
\text { Geliştirme }\end{array}$ & 3,917 & 0,741 & $\begin{array}{l}, 742^{+} \\
+ \\
\end{array}$ &, $541^{++}$ & ,491++ & $\begin{array}{l}210 \\
+ \\
\end{array}$ & $\begin{array}{l}, 543 \\
+ \\
+\end{array}$ & ,697++ & 1 & & \\
\hline 8 & $\begin{array}{l}\text { Yeni Hizmet } \\
\text { Geliştirme } \\
\text { Ortam }\end{array}$ & 4,036 & 0,727 & $\begin{array}{l}\text {,638+ } \\
+\end{array}$ & $486^{++}$ & $410^{++}$ & ,162 & $\begin{array}{l}, 507 \\
++\end{array}$ &, $590^{++}$ & $\begin{array}{l}\text {,784 } \\
++\end{array}$ & 1 & \\
\hline 9 & $\begin{array}{l}\text { Yeni Hizmet } \\
\text { Geliştirme } \\
\text { Destek }\end{array}$ & 3,845 & 0,882 & $\begin{array}{l}678^{+} \\
+\end{array}$ & $488^{++}$ & $447^{++}$ & $\begin{array}{l}\text {,203 } \\
+\end{array}$ & $\begin{array}{l}493 \\
++\end{array}$ & $642^{++}$ & $\begin{array}{l}957 \\
++\end{array}$ & $\begin{array}{l}\text {,587 } \\
++\end{array}$ & 1 \\
\hline
\end{tabular}

${ }^{+} \mathrm{p}<0,01,{ }^{+} \mathrm{p}<0,05$

Tablo 1.'de görüldüğü gibi, strateji odaklılık ile yeni hizmet geliştirme arasında $(r=0,742 ; p<0,05)$, yüksek ilişki tespit edilmiştir. Pazar odaklılık ile yeni hizmet geliştirme Spearman korelasyon değerleri $\mathrm{r}=0,541 \quad(\mathrm{p}<0,05)$ olup, orta düzeyde bir ilişkiden teknoloji odaklılık ile yeni hizmet geliştirme arasında $r=0,697(p<0,05)$ ile yüksek oranlı bir ilişki söz konusudur. Korelasyon analizi sonuçlarında, pazar odaklılık ile yeni hizmet geliştirmenin ortam alt boyutu arasında $(\mathrm{r}=0,486$; $\mathrm{p}<0,05)$ ve pazar odaklılık ile yeni hizmet geliştirmenin destek alt boyutu arasında $(r=0,488$; $\mathrm{p}<0,05)$ zayıf güçte ilişkilerin olduğu görülmüştür. Teknoloji odaklılık ile yeni hizmet geliştirmenin ortam alt boyutu için $r=0,590(p<0,05)$, teknoloji odaklılık ile yeni hizmet geliştirmenin destek alt boyutu için $r=0,642(p<0,05)$ olup her iki ilişkinin de orta düzeyde olduğu görülmüştür. Pazar odaklılı̆̆ın müşteri alt boyutu ile yeni hizmet geliştirmenin ortam alt boyutu arasında zayıf $(r=0,410 ; \mathrm{p}<0,05)$, pazar odaklılığın fonksiyonlar arası koordinasyon alt boyutu ile yeni hizmet geliştirmenin ortam alt boyutu arasında orta $(\mathrm{r}=0,507 ; \mathrm{p}<0,05)$ düzeyde ilişkilerin varlığı görülmektedir. Ancak pazar odaklılığın rakip alt boyutu ile yeni hizmet geliştirme ortam arasında herhangi bir ilişkiye rastlanmamıştır. Pazar odaklılığın müşteri alt boyutu ile yeni hizmet geliştirmenin destek alt boyutu arasında $(\mathrm{r}=0,447 ; \mathrm{p}<0,05)$ zayıf ilişki olmasına rağmen anlamlı ve olumlu yönlü ilişkiden bahsedilmektedir. Pazar odaklılı̆̆ın rakip alt boyutu ile yeni hizmet geliştirmenin destek alt boyutu arasındaki ilişkide çok zayıf $(r=0,203 ; p<0,05)$ ama olumlu ve anlamlı sonuç bulunmuştur. Pazar odaklılığın fonksiyonlar arası koordinasyon alt boyutu ile yeni hizmet geliştirmenin destek alt boyutu arasında da orta düzeyde $(r=0,493 ; p<0,05)$ olumlu ve anlamlı bir ilişki görülmüştür. Bu durumda sadece pazar odaklılık değişkenimizin rakip odaklılık boyutu ile yeni hizmet geliştirmenin ortam boyutu arasında anlamlı herhangi bir ilişkiye rastlanmamıştır. 


\section{Regresyon Analizi}

Çalışmada korelasyon analizi neticesinde anlamlı bulunan ilişkilere ilişkin strateji odaklılık ve alt boyutlarının yeni hizmet geliştirme alt boyutları üzerindeki etkisini belirlemek amacıyla regresyon analizi yapılmıştır. Bu analizlere ait regresyon modelleri korelasyon analizinde bulunan ilişkileri destekler niteliktedir.

Tablo 2. Strateji Odaklılığın Yeni Hizmet Geliştirmeye Etkisi Bağımlı Değişken: Yeni Hizmet Geliştirme

\begin{tabular}{l|c|c|c}
\hline Bağımsız Değişken: & $\boldsymbol{\beta}$ & $\boldsymbol{t}$ & $\boldsymbol{p}$ \\
\hline Strateji Odaklılık & 0,741 & 12,812 & $\mathbf{0 , 0 0 0}$ \\
\hline $\boldsymbol{R}^{2}=\mathbf{0 , 5 4 9 ;}$ & Düzeltilmiş $\boldsymbol{R}^{\mathbf{2}=\mathbf{0 , 5 4 5} ;}$ & $\boldsymbol{F = 1 6 4 , \mathbf { 1 4 5 } ;}$ & $\boldsymbol{p = 0 , 0 0 0}$ \\
\hline
\end{tabular}

Çalışmada oluşturulan ilk model strateji odaklılığın yeni hizmet geliştirmeyi ne ölçüde etkilediğini açıklamaya yöneliktir. Analiz sonucunda (Tablo 2.), yeni hizmet geliştirmenin $\% 55$ 'inin strateji odaklılık değişkeni tarafından açıklandığı görülmektedir. Bunun yanında 0,741 değerindeki standart beta değeri, strateji odaklılık değişkeninde bir birimlik değişimin yeni hizmet geliştirmede meydana getirebileceği değişimin oranını göstermektedir. Bu sonuçlara göre, araştırmanın ilk hipotezi " $1 \mathrm{H}_{1}$ : Strateji odaklılığın yeni hizmet geliştirme üzerinde anlamlı etkisi vardır" hipotezi kabul edilmiştir. Araştırmanın bu sonucu, Oflazoğlu ve Koçak (2012:1) tarafından yürütülen çalışmada elde edilen strateji odaklılık ve yenilik arasındaki olumlu ilişkinin varlığı sonucunu desteklemektedir. Oflazoğlu ve Koçak (2012:1) aynı çalışmada ilişkinin yönünü ve kuvvetini belirleyen regresyon analizi ile strateji odaklılı̆̆ın yenilik üzerinde olumlu bir etkiye sahip olduğunu da belirtmişlerdir. Uzun vadeli ve ortalamanın üzerinde bir karı hedefleyen strateji odaklılık, işletmede yeni hizmet geliştirmeyi olumlu doğrultuda etkileyebilmektedir.

Tablo 3. Strateji Odaklılığın Alt Boyutlarının Yeni Hizmet Geliştirme Ortamına Etkisi

\begin{tabular}{|c|c|c|c|}
\hline \multicolumn{4}{|c|}{ Bağımlı Değişken: Yeni Hizmet Geliştirme-Ortam } \\
\hline Bağımsız Değişken: & $\beta$ & $t$ & $p$ \\
\hline Pazar Odaklılık & 0,236 & 3,251 & 0,001 \\
\hline Teknoloji Odaklılık & 0,505 & 6,940 & 0.000 \\
\hline
\end{tabular}

Strateji Odaklılık değişkeninin alt boyutları olan pazar ve teknoloji odaklılı̆̆ın yeni hizmet geliştirme ortamı üzerindeki etkisinin test edildiği regresyon analizi sonucuna göre (Tablo 3.), "1Hı: Strateji odaklılığın alt boyutlarının yeni hizmet geliştirme ortamı üzerinde anlamlı etkisi vardır." hipotezi kabul edilmiştir. Strateji odaklılık alt boyutlarından teknoloji odaklılığın yeni hizmet geliştirme ortamı üzerindeki etkisinin pazar odaklılığa nazaran daha yüksek olduğu görülmektedir.

Tablo 4. Strateji Odaklılı̆̆ın Alt Boyutlarının Yeni Hizmet Geliştirme Desteğine Etkisi Bağımlı Değişken: Yeni Hizmet Geliştirme-Destek

\begin{tabular}{|c|c|c|c|}
\hline Bağımsız Değişken: & $\beta$ & $t$ & $p$ \\
\hline Pazar Odaklılık & 0,247 & 3,576 & 0,000 \\
\hline Teknoloji Odaklılık & 0,543 & 7,864 & 0,000 \\
\hline$R^{2}=0,465$ & \multicolumn{3}{|c|}{ Düzeltilmiş $R^{2}=0,457 ; \quad F=58,223$} \\
\hline
\end{tabular}


Strateji Odaklılık değişkeninin alt boyutları olan pazar ve teknoloji odaklılı̆̆ın yeni hizmet geliştirme desteği üzerindeki etkisi incelendiğinde (Tablo 4.), benzer şekilde olumlu etkinin varlığı görülmektedir. Bu durumda, "1 $\mathrm{H}_{1 \mathrm{~b}}$ : Strateji odaklılığın alt boyutlarının yeni hizmet geliştirme desteği üzerinde anlamlı etkisi vardır." hipotezi de kabul edilmiştir. Tablo 3. ve Tablo 4.'te görülen etkiler incelendiğinde, bu çalışmada da ilgili literatürde farklı yazarlarca gerçekleştirilen çalışmalarda (Atuahane-Gima 1995:275; Lado ve Maydeu-Olivares 1998:1) olduğu gibi, pazar odaklılığın yeni hizmet geliştirme üzerinde olumlu etkisinin varlığı ortaya konmuştur. Ayrıca, Lukas ve Ferrell (2000:239), Deshpande vd., (1993:31) ve Koçak ve Karaca (2013:45-46)'nın çalışmalarında da pazar odaklılık ile yenilik arasındaki olumlu ilişkiden söz edilmekte, hatta pazar odaklılığın yeniliği olumlu yönde etkilediği vurgulanmaktadır. Teknoloji odaklılık alt boyutu ile ilgili sonuçlar incelendiğinde ise, bu çalışmanın sonuçları ile Salavou (2005:1)'nun KOBİlerin sahip olduğu teknoloji odaklılığın yeni hizmet geliştirme uygulamaları ile birlikte ürün yeniliği başarısını etkilediği, böylece yeni ürün/hizmetler geliştirme konusunda etkin olabildiklerini ifade edilen çalışmasının sonuçları ile uyumlu olduğu görülmektedir.

Pazar odaklılığın alt boyutları olan müşteri odaklılık, rakip odaklılık ve fonksiyonlar arası koordinasyon değişkenlerinin hem yeni ürün geliştirme ortamı hem de yeni ürün geliştirme desteği üzerindeki etkisi yine regresyon analizleri ile incelenmiş olup, sonuçlar Tablo 5.'te görülmektedir. Alt boyutlardan rakip odaklılığın korelasyon analizlerinde yeni hizmet geliştirme ortamı ile ilişkisi tespit edilemediğinden burada regresyon analizine dahil edilmemiştir.

Tablo 5. Pazar Odaklılığın Alt Boyutlarının Yeni Hizmet Geliştirme Ortam ve Desteğine Etkisi Bağımlı Değişken: Yeni Hizmet Geliştirme-Ortam

\begin{tabular}{|c|c|c|c|}
\hline Bağımsız Değişken: & $\beta$ & $t$ & $p$ \\
\hline Müşteri Odaklılık & 0,309 & 3,777 & 0,000 \\
\hline$R^{2}=0,096$ & Düzeltilmiş $\boldsymbol{R}^{2}$ & $F=1$ & $p=0,000$ \\
\hline
\end{tabular}

Bağımlı Değişken: Yeni Hizmet Geliştirme-Destek

\begin{tabular}{|c|c|c|c|}
\hline Bağımsız Değişken: & $\beta$ & $t$ & $p$ \\
\hline Müşteri Odaklılık & 0,369 & 4,606 & 0,000 \\
\hline$R^{2}=0,136$ & Düzeltilmiş $\boldsymbol{R}^{2}$ & $F=2$ & $p=0,00$ \\
\hline
\end{tabular}

Bağımlı Değişken: Yeni Hizmet Geliştirme-Destek

\begin{tabular}{l|c|c|c}
\hline Bağımsız Değişken: & $\boldsymbol{\beta}$ & $\boldsymbol{t}$ & $\boldsymbol{p}$ \\
\hline Rakip Odaklılık & 0,137 & 1,612 & $\mathbf{0 , 1 0 9}$ \\
\hline $\boldsymbol{R}^{2}=\mathbf{0 , 0 1 9 ;}$ & Düzeltilmiş $\boldsymbol{R}^{\mathbf{2}=\mathbf{0 , 0 1 2} ;}$ & $\boldsymbol{F = 2 , 5 9 9 ;}$ & $\boldsymbol{p = 0 , 1 0 9}$ \\
\hline
\end{tabular}

Bağımlı Değişken: Yeni Hizmet Geliştirme-Ortam

\begin{tabular}{|c|c|c|c|}
\hline Bağımsız Değişken: & $\beta$ & $t$ & $p$ \\
\hline $\begin{array}{l}\text { Fonksiyonlar } \\
\text { Koordinasyon }\end{array}$ & 0,514 & 6,963 & 0,000 \\
\hline$R^{2}=0,264$ & Düzeltilmiş $R^{2}=0,259$; & $F=48,478$ & $p=0,000$ \\
\hline
\end{tabular}

Bağımlı Değişken: Yeni Hizmet Geliştirme-Destek

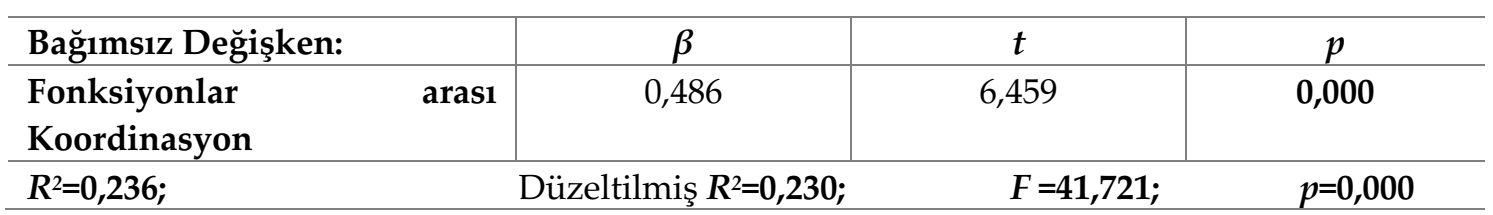


Pazar odaklılık değişkenini oluşturan unsurlardan biri müşteri odaklılıktır. Bu bağlamda müşteri odaklılık değişkeni yeni hizmet geliştirme ortam değişkenini \%9,6 oranında açıklamakta olup p değeri (P: 0,000) anlamlıdır. Müşteri odaklılık değişkenindeki bir birimlik artış yeni hizmet geliştirmenin ortam değişkeninde 0,309 birimlik artışa neden olabilecektir. Bu durumda " $2 \mathrm{H}_{1 \mathrm{Aa}}$ Müşteri odaklılığın yeni hizmet geliştirmenin ortamı üzerinde anlamlı etkisi vardır" hipotezi kabul edilmiştir. Müşteri odaklılık değişkeni, yeni hizmet geliştirme destek değişkenini \%13 oranında açıklamaktadır. Ayrıca 0,369 standart beta değeri ile yeni hizmet geliştirmenin destek değişkeni müşteri odaklılık değişkeni ile anlamlı bir şekilde öngörülebilmektedir. Dolayısıyla "2 $\mathrm{H}_{1 \mathrm{Ab}}$ : Müşteri odaklılığın yeni hizmet geliştirmenin desteği üzerinde anlamlı etkisi vardır" hipotezi de kabul edilmiştir. Adams, Fireitas ve Fontana (2019:134) müşteri odaklılığın doğrudan yeni hizmet geliştirme üzerinde olmasa da yenilik performansı üzerinde olumlu etkisi olduğunu ortaya koymuştur.

Pazar odaklılığın diğer bir alt boyutu, rakip odaklılık değişkenidir. Korelasyon analizi doğrultusunda rakip odaklılık ile sadece yeni hizmet geliştirme destek değişkeni arasında zayıf düzeyde ilişki görülmüş ve bu doğrultuda regresyon modeli oluşturulmuştur. Ancak modelde $p$

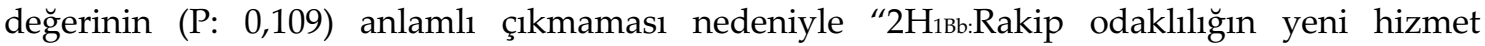
geliştirmenin desteği üzerinde anlamlı etkisi vardır" hipotezi red edilmiştir. Grawe vd., (2009:282) pazar odaklılığın iki alt boyutu olan rakip odaklılık ve müşteri odaklılık ile hizmet yeniliği arasında olumlu ilişki tespit etmiştir. Lewrick, Omar ve Williams (2011:56) start-up ve gelişmiş işletmelerde müşteri ve rakip odaklılığın yenilik üzerindeki etkisini incelemiştir. Startup işletmelerde müşteri odaklılık ile sadece artımsal yenilik arasında, rakip odaklılık ile ise, hem artımsal hem de radikal yenilik arasında olumlu ilişkiler bulmuştur. Gelişmiş işletmelerde ise, müşteri odaklılığın her iki yenilik türü ile olumlu ilişkisine rastlanırken, rakip odaklılık ile radikal yenilik arasında olumsuz ilişki bulunmuştur. Bu çalışma sonuçlarında ise, hizmet yeniliği üzerinde müşteri odaklılığın olumlu etkisi görülürken, rakip odaklılığın etkisine rastlanmamıştır.

Pazar odaklılığın alt boyutu olan fonksiyonlar arası koordinasyon değişkeni ise, yeni hizmet geliştirmenin ortam değişkenini \%26 oranında açıklamakta olup p değeri (P: 0,000) anlamlıdır. Fonksiyonlar arası koordinasyon değişkenindeki bir birimlik artış, yeni hizmet geliştirme ortam değişkeninde 0,514'lük bir artışa neden olabilmektedir. Bu durumda "2Hıca: Fonksiyonlar arası koordinasyonun yeni hizmet geliştirme ortamı üzerinde anlamlı etkisi vardır" hipotezi kabul edilmiştir. Fonksiyonlar arası koordinasyon değişkeni yeni hizmet geliştirmenin destek değişkenini \%23 oranında açıklamaktadır. Ayrıca, fonksiyonlar arası koordinasyon değişkenindeki bir birimlik artış, yeni hizmet geliştirme destek değişkeninde 0,486'lık bir artışa neden olabilmektedir. Dolayısıyla, "2 $\mathrm{H}_{1 \mathrm{cb}}$ : Fonksiyonlar arası koordinasyonun yeni hizmet geliştirme desteği üzerinde anlamlı etkisi vardır" hipotezi de kabul edilmiştir. Ho vd., (2018:154) de benzer şekilde fonksiyonlar arası koordinasyonun yenilik ile olumlu ilişkisinden bahsetmektedir. Wang ve Miao (2015:2378)'nun pazar odaklılığın alt boyutlarının yenilikle bağlantılı sonuçlar ile ilişkisini incelediği çalışmada da müşteri odaklılık, rakip odaklılık ve fonksiyonlar arası koordinasyonun yenilik kültürü ile ilişkisi doğrulanmıştır. Bu çalışmada elde edilen yeni ürün geliştirme ortamı üzerinde müşteri odaklılığın ve fonksiyonlar arası koordinasyonun olumlu etkisi aynı doğrultuda bir sonuçtur.

\section{SONUÇ ve ÖNERILER}

Araştırma Trakya Bölgesi'nde yerli ve yabancı misafirlere hizmet veren konaklama işletmelerinde gerçekleştirilmiştir. Araştırma verileri genel müdür, müdür, departman amirleri ve departman şeflerinden oluşan yöneticilerden anket tekniği ile elde edilmiştir. Çalışmada, konaklama işletmelerindeki strateji odaklılık ile yeni hizmet geliştirme arasındaki ilişki belirlenmeye yönelik bir model oluşturulmuştur. Oluşturulan kavramsal modelde yeni hizmet 
geliştirmeyi etkileyen strateji odaklılık değişkeni, pazar ve teknoloji odaklılık boyutları altında ele alınmıştır. Ayrıca pazar odaklılık değişkeni de ilgili literatüre dayalı olarak; müşteri odaklılık, rakip odaklılık ve fonksiyonlar arası koordinasyon olarak üç alt boyut ile incelenmiştir. Analizler sırasında, yeni hizmet geliştirme değişkeni iki alt boyuta ayrılarak, analizlerin devamında yeni hizmet geliştirme ortam ve yeni hizmet geliştirme destek olarak incelenmiştir.

Araştırmada belirlenen ana hipotez çerçevesinde yürütülen analizlerde strateji odaklılığın yeni hizmet geliştirme üzerinde anlamlı ve olumlu bir etkisi olduğu görülmüştür. Konaklama işletmelerinin değişen pazar koşullarına uyum sağlamak için rekabet üstünlüğü elde etmesinin anahtarı, yeni ürün ve hizmet geliştirmeleridir. Yeni hizmetlerin geliştirilebilmesine yönelik çabalar, strateji odaklı bakış açısı ile desteklenirse başarı olasılı̆̆ı da artacaktır.

Strateji odaklılığın iki alt boyutu olarak kabul edilen pazar odaklılık ve teknoloji odaklılık değişkenlerinin yeni hizmet geliştirme (ortam ve destek) üzerindeki etkisi incelendiğinde ise, bulgular, pazar odaklılığın yeni hizmet geliştirme üzerindeki olumlu etkisini göstermiştir. Konaklama işletmelerindeki pazar odaklı (müşteri odaklılık, rakip odaklılık ve fonksiyonlar arası koordinasyon) çalışmalar kapsamında yeni hizmet geliştirme üzerinde olumlu etkiler gösterebileceği anlaşılmaktadır. Bunun sonucunda da yeni hizmet gelişimi sağlayabilmeleri pazar odaklı bakış ile mümkün olacağı düşünülebilir.

Çalışmada pazar odaklı bakışın yeni hizmet geliştirmede hem çalışma ortamındaki mevcut durum ile hem de çalışanlara sunulan fırsatlar ile yakın ilişki içinde olduğu görülmektedir. Müşteri odaklılığın ve fonksiyonlar arası koordinasyonun hem yeni hizmet ortamı hem de yeni hizmet geliştirme desteği üzerinde olumlu etkisi görülmüştür. Yeni hizmet geliştirme konusunda gelişme kaydetmek isteyen konaklama işletmelerinin öncelikle kendi içlerinde müşteri odaklı bir yapıyı sağlamalarının önemi bu sonuçlarla ortaya konmuştur. Etki düzeyleri incelendiğinde ise, konaklama işletmesinin tüm fonksiyonlarının koordineli bir biçimde çalışmasının yeni hizmet geliştirme üzerinde daha büyük bir etkiye sahip olduğu görülmektedir. Dolayısıyla araştırma ve yazın taraması sonuçlarına göre, müşteri beklentilerini tespit eden, rakiplerini gözlemleyen ve bu bilgileri işletme fonksiyonları arasında koordineli bir şekilde kullanan işletmelerin yeni hizmet/ürün geliştirme eğilimlerinin daha yüksek olduğu anlaşılmaktadır.

Çalışmanın teknoloji odaklılık değişkeninin hem yeni hizmet geliştirme ortamını hem de yeni hizmet geliştirmeye verilen desteği olumlu etkilediği sonucu, konaklama işletmelerinde teknoloji odaklılığın işletmelerin yeni hizmet geliştirme düzeylerini arttıracağ güçlendirmektedir. İşletmelerin karmaşık teknolojiler kullanması, yeni teknolojilerin yöneticiler tarafından kabul görmesi doğal olarak yeni hizmet gelişimini destekleyecektir. Teknoloji geliştirme konusunda izlenecek proaktif stratejiler sayesinde, işletmelerin sahip olduğu kaynakların yenilik çalışmalarına yönlendirilmesi, eğitim ile insan gücüne yatırım yapılması ve ödüllendirme mekanizmalarının kullanılması yeni hizmet geliştirmede fırsat olarak kullanılabilecektir.

Tüm bulgular bir arada değerlendirildiğinde, konaklama işletmelerinin yeni hizmet geliştirme ortamı yaratmasında ve yeni hizmet geliştirme konusunda çalışanları desteklemesinde, bu çalışma kapsamında ele alınan kavramlar arasında en önemli olanın teknoloji odaklılık olduğu görülmektedir. Daha sonra ise fonksiyonlar arası koordinasyon ve müşteri odaklılık gelmektedir. Fakat tüm bu faktörlerin bir bütünlük içinde ele alınarak iyileştirilmesinin yeni hizmet geliştirme kabiliyeti üzerinde olumlu etki yapabileceği öngörülmektedir. 
Araştırma Trakya Bölgesi konaklama işletmeleri ile sınırlandırılmıştır. Araştırma bölgesinin sınırlarının genişletilmesi araştırmanın genellenebilmeye yaklaşmasına yardımcı olacaktır. Ayrıca, araştırmada ele alınan değişkenlerin farklı değişkenler eklenerek test edilmesi de konaklama işletmelerinde yeni hizmet geliştirilmesine katkı sağlayacak akademik çalışmaları arttıracaktır.

Pazar odaklı bakış açısı aynı zamanda yöneticilerin çalışanlarına yenilik yapma konusundaki yaratıcılığını geliştirici fırsatların verilmesini sağlayacaktır. Yöneticilerin çalışanlarını dikkate alması, iş üzerinde özerklik tanıması, güven oluşturması, ödül sistemleri, kaynak tahsisi ve insan gücüne yatırımın arttırılması, yeni hizmet gelişimini destekleyerek işletmeyi hedeflerine daha çabuk ulaştıracaktır. Konaklama işletmelerinde müşterilerin beklentilerini, memnuniyetlerine ilişkin bağlılıklarını düzenli olarak değerlendirilip, izleyen bir ekibin olması, geliştirilen yeni hizmetlerin zamanlama, işleyiş ve kaynaklar bakımından etkili olmasını sağlayacaktır. Konaklama işletmelerinde dijital dönüşüme adım atmayı sağlayacak bilgi işlem teknolojisi altyapısına yatırım yapılması, yeni hizmet geliştirme ve müşterilere sunumunda çağın gereklerini karşılamaya katkı sağlayabilir. Bu nedenle, teknolojiye yapılan yatırımlara ayrılan kaynakların arttırılması ve etkin kullanılması, rekabet üstünlüğü sağlamada konaklama işletmelerine avantaj sağlayacaktır.

\section{KAYNAKÇA}

Adams, P., Freitas, I.M.B. and Fontana, R. (2019). Strategic Orientation, Innovation Performance and the Moderating Influence of Marketing Management, Journal of Business Research, 97:129-140.

Adıgüzel, B. (2012). İnovasyon ve İnovasyon Yönetimi: Steve Jobs Örneği, Yayınlanmamış Yüksek Lisans Tezi, Gazi Üniversitesi, Ankara.

Agarwal, S., Erramilli, K.M. and Dev, S. C. (2003). Market Orientation and Performance in Service Firms: Role of Innovation, Journal of Services Marketing, 17 (1): 68-82.

Akgemci, T., ve Güleş H.K. (2010). İşletmelerde Stratejik Yönetim, Ankara: Özbaran Ofset Matbaacilik.

Akman, G., Özkan, C. ve Eriş, H. (2008). Strateji Odaklılık ve Firma Stratejilerinin Firma Performansına Etkisinin Analizi, İstanbul Ticaret Üniversitesi Fen Bilimleri Dergisi, 17 (13): 93-115.

Akman, G. and Yılmaz, C. (2008). Innovative Capability, Innovation Strategy and Market Orientation: An Empirical Analysis in Turkish Software Industry", International Journal of Innovation Management, 12 (1): 69- 111.

Atuahene-Gima, K. (1995). An exploratory analysis of the impact of market orientation on new product performance: a contingency approach, Journal of Product Innovation Management: An International Publication of The Product Development \& Management Association,12 (4): 275-293.

Atuahene-Gima, K. and Ko, A. (2001). An Empirical Investigation of the Market Orientation and Entrepreneurship Orientation Alignment on Product Innovation, Organization Science, 12 (1): 5474. 
Avlonitis, J.G., Papastathopoulou, G. P. and Gounaris, P. S. (2001). An Empirically-Based Typology of Product Innovativeness for New Financial Services: Success and Failure Scenarios, Journal of Product Innovation Management, 18 (5): 324-342.

Ayyıldız Ünnü N.A. (2009). Politik Pazarlamada Pazar Yönlülük ve Otantik Liderliğin Önemi, Ege Akademik Bakış, 9 (4): 1243-1273.

Biçimveren, L. (2017). Pazar Odaklllı, Yenilik Odaklılık, Pazarlama İnovasyonu ve Uluslararası Pazar Performansı: Balıkesir ve Bursa illerinde Dış Ticaret Yapan Firmalara Yönelik Bir Uygulama, Yayınlanmamış Yüksek Lisans Tezi, Balıkesir Üniversitesi, Balıkesir.

Bulut, Ç., Alpkan, L. ve Yılmaz, C. (2009). Stratejik Oryantasyonlar ve Firma Performansı İlişkisi: Literatür Gelişimi Üzerine Kavramsal Bir çalışma, İşletme Fakültesi Dergisi, 10 (1): 1-34.

Calantone, J.R., Chan, K. and Cui, S.A. (2006). Decomposing product innovativeness and its Effects on New Product Success, Journal of Product Innovation Management, 23(5): 408-421.

Cheng, C.C. and Krumwiede, D. (2012). The Role of Services Innovation in the Market Orienttaion- New Service Performance Linkage, Technovation, 32: 487-497.

Çınar, K. (2017). Otel İşletmelerinde Yenilik Algısı ve Uygulamaları, Aksaray Üniversitesi İktisadi ve İdari Bilimler Fakültesi Dergisi, 9 (2): 37-50.

Damanpour, F. (1996). Organizational Complexity and Innovation: Developing and Testing Multiple Contingency Models, Management Science,42(5): 693-716.

Deng, S. and Dart, J. (1994). Measuring Market Orientation: A Multi Factor, Multi -Item Approach, Journal of Marketing Management, 10(8): 725-742.

Deshpande, R., Farley, U.J. and Webster, E.F. (1993). Corporate Culture, Customer Orientation, and Innovativeness in Japanese Firms: A Quadrad Analysis, Journal of Marketing, 57 (1): 23-37.

Dinçer, H. (2010). Bankacıllk Sektöründe Yeni Hizmet Geliştirmenin Rekabet Stratejilerindeki Değişime Etkisi, (Marmara Üniversitesi, Bankacilık ve Sigortacılık Enstitüsü, Basılmamış Doktora Tezi), İstanbul.

Durna, U. (2002). Yenilik Yönetimi, Ankara: Nobel Yayın Dağıtım.

Elçi, Ş. (2007). İnovasyon Kalkınma ve Rekabetin Anahtarı, İstanbul:TYD.

Escriba- Esteve, A., Sanchez-Peinado, L. and Sanchez-Peinado, E. (2009). The Influence of Top Management Teams in the Strategic Orientation and Performance of Small and Medium-sized Enterprises, British Journal of Management, 20 (4): 581-597.

Gatignon, H. and Xuereb, J. M. (1997). Strategic Orientation of the Firm and New Product Performance, Journal of Marketing Research, 34 (1): 77- 90.

Gökçek, O. (2007). Yenilik Yönetimi Süreci ve Yenilik Stratejileri: Otomotiv Sektöründe Bir Alan Araştırması, Yayınlanmamış Yüksek Lisans Tezi, İstanbul Üniversitesi, İstanbul. 
Gray, B., Matear, S., Boshoff, C. and Matheson, P. (1998). Developing a Better Measure of Market Orientation, European Journal of Marketing, 32 (9/10): 884-903.

Grawe, S.J., Chen, H. and Daugherty, P.J. (2009). The Relationship Between Strategic Orientation, Service Innovation and Performance, International Journal of Physical Distribution Logistic Management, 39 (4): 282-300.

Halaç, D.S. (2014). The Effects of Technology Orientation on Firm Performance, Doctor of Philosophy, Yaşar University, Graduate School of Social Sciences Department of Business Administration, İzmir.

Halaç, D.S. (2015). Multidimensional Construct of Technology Orientation, Procedia-Social and Behavioral Sciences, 195: 1057-1065.

Harsono, M. and Haryono, T. (2014). The Relationship Between Orientation and Marketing Performance: The Role of Organizational Change Capability, American International Journal of Contemporary Research, 4 (1): 221- 229.

Ho, K. Le P., Nguyen, C. N., Adhikari, R., Miles, M.P. and Bonney, L. (2018). Exploring Market Orientation, Innovation, and Financial Performance in Agriculture Value Chains in Emerging Economies, Journal of Innovation \& Knowledge, 3 (3): 154-163.

Hu, M.M., Horng, J. and Sun, Y.C. (2009). Hospitality Teams: Knowledge Sharing and Service Innovation Performance, Tourism Management, 30 (1): 41-50.

Işık, M. (2018). İnovasyon Kültürünün Hizmet İnovasyonu Performansına Etkisi: Bitlis İli Hizmet Sektöründe Bir Araştırma, Atatürk Üniversitesi İktisadi ve İdari Bilimler Dergisi, 32 (2): 351-366.

Jaworski, J.B. and Kohli, K.A. (1993) Market Orientation: Antecedents and Consequences, Journal of Marketing, 57: 53-70.

Jeong, I., Pae, H.J. and Zhou, D. (2006). Antecedents and Consequences of the Strategic Orientations in New Product Development: The Case of Chinese Manufactures, Industrial Marketing Management, 35: 348-358.

Karabulut, T.A. (2015). Effects of Innovation Strategy on Firm Performance: A Study Conducted on Manufacturing Firms in Turkey, Procedia Social and Behavioral Sciences, 195: 1338-1347.

Karamustafa, K., Güllü, K., Acar, N. ve Ulama, Ş. (2010). Konaklama İşletmelerinde Pazar Odaklılık Uygulamalarl, Ankara: Detay Yayıncilı.

Koçak, A. ve Karaca, K. (2013). İşletmelerde Örgütsel Karakteristiklerin Yenilik Kapasitesi Üzerine Ortaklaşa Etkisinin Belirlenmesi, Pazarlama ve Pazarlama Araştırmaları Dergisi, 11: 21-60.

Kohli, K.A. and Jaworski, J.B. (1990). Market Orientation: The Construct, Research Propositions, and Managerial Implications, Journal of Marketing, 54: 1-18. 
Küçük, O. ve Kocaman, G. (2014). Müşteri Yönlülük, İnovasyon Yönlülük ve İşletme Performans İlişkisi: Bir Uygulama, The Journal of Academic Social Science Studies, 29: 37-52.

Lado, N. and Maydeu-Olivares, A. (1998). Exploring the Link Between Market Orientation and Innovation in The European and US Insurance Markets, Business Economic Series, 1-18.

Lewrick, M., Omar M., and Williams, Jr.R.L. (2011). Market Orientation and Innovators' Success: An Exploration of the Influence of Customer and Competitor Orientation, Journal of Technology Management \& Innovation, 6(3):48-62.

Lita, R.P., Meuthia, and Faisal, R. F. (2018). SME's Performance of Creative Industries Supporting Tourism in Indonesia: Market Orientation, Learning Orientation and Organizational Innovativeness as Determinants, Academy of Marketing Studies Journal, 22(1):1-18.

Liu, X. and Revell. B.J. (2009). Competitiveness changes in China's quality vegetable exports postWTO, Journal of Chinese Economic and Foreign Trade Studies 2: 86-99.

Liu, C. and Chen, Y. (2015). Strategy Orientation, Product Innovativeness, and New Product Performance, Journal of Management Organizational, 21 (1): 2-16.

Lopez, P.S., Peon, J.M.M and Ordas, C.J.V. (2005). Organizational Learning as a Determining Factor in Business Performance, The Organizational Learning, 12 (3): 227-245.

Lu, Q. and da Gama, V. (2007). Inter-Functional Coordination for New Service Development, Proceedings of International Conference on Industrial Engineering and Engineering Management. IEEE IEEM:1423-1427.

Lukas, B.A., and Orville, C.F. (2000). The Effect of Market Orientation on Product Innovation, Journal of The Academy of Marketing Science, 28 (2): 239-247.

Matear, S., Gray, J.B. and Garrett, T. (2004). Market Orientation, Brand Investment, New Service Development, Market Position and Performance for Service Organisations, International Journal of Service Industry Management, 15 (3): 284-301.

Naktiyok, A. (2003). Yönetici Değerleri ve Pazar Yönlülük Bir Uygulama, Erciyes Üniversitesi İktisadi ve İdari Bilimler Fakültesi Dergisi, 20: 95- 116.

Narver C.J. and Slater, F.S. (1990). The Effect of a Market Orientation on Business Profitability, Journal of Marketing, 54 (4): 20-35.

Oflazoğulu, S. ve Koçak, A. (2012). Stratejik Yönlülüklerin Yenilik ve Performans Arasındaki İlişki, Çankırı Karatekin Üniversitesi İktisadi ve İdari Bilimler Fakültesi Dergisi, 2 (1): 121-144.

OECD (2006). Oslo Kılavuzu: Yenilik Verilerinin Toplanması ve Yorumlanması İçin İlkeler (Cilt 3. Bask1). Tübitak.

Oslo Kılavuzu (2005). Yenilik Verilerinin Toplanması ve Yorumlanması İçin İlkeler, 3.Baskı, OECD, Avrupa Komisyonu, Türkçe Baskısı: TÜBİTAK. 
Ostrom, A.L., Bitner, M.J., Brown S.W., Burkhard, K.A., Goul, M., Smith-Daniels, V. Demirkan, H. and Rabinovich, E. (2010). Moving Forward and Making a Difference: Research Priorities for the Science of Service, Journal of Service Research, 13 (1): 4-36.

Ottenbacher, C.M. and Harrington J.R. (2010). Strategies for Achieving Success for Innovative Versus Incremental New Services, Journal of Services Marketing, 24 (1): 3-15.

Panda, H. and Ramanathan, K. (1996). Technological Capability Assessment of a Firm in the Electricity Sector, Technovation, 16 (10): 561-588.

Polder, M., Leeuwen, G.V., Mohnen, P. and Raymond, W. (2010). Product, Process and Organizational Innovation: Drivers, Complementarity and Productivity Effects, MERIT Working Papers 035, United Nations University - Maastricht Economic and Social Research Institute on Innovation and Technology (MERIT).

Ruekert, W.R. (1992). Developing a Market Orientation: An Organizational Strategy Perspective, International Journal of Research in Marketing, 9 (3): 225-245.

Salavou, H. (2005). Do Customer and Technology Orientations Influence Product Innovativeness in SMEs? Some New Evidence from Greece, Journal of Marketing Management, 21 (3-4): 307-338.

Shapiro, P.B. (1988). What the Hell is Market Oriented?, Harvard Business Review, 66 (6): 119-125.

Slater, F.S. and Narver, C.J. (1994). Does Competitive Environment Moderate the Market Orientation- Performance Relationship? Journal Marketing, 58: 46-55.

Slater, F.S. and Narver, C.J. (1995). Market Orientation and the Learning Organization, Journal of Marketing, 59: 63-74.

Srithika, T.M. and Bhattacharyya, S. (2009). Facilitating Organizational Unlearning Using Appreciative Inquiry as an Intervention, Vikalpa, 34 (4): 67-77.

Storey, C. and Easingwood, C.J. (1999). Types of New Product Performance: Evidence from the Consumer Financial Services Sector, Journal of Business Research, 46(2):193-203.

Sürer, A. (2012). E-Pazarlama Yöneliminin İhracat Performansı Üzerindeki Etkisi: Gaziantep İlinde Bir Araştırma, Yayınlanmamış Yüksek Lisans Tezi, Gaziantep Üniversitesi, Gaziantep.

Tsou, H., Chen, J. and Liao, W. (2014). Market and Technology Orientations for Service Delivery Innovation: The Link of Innovative Competence, Journal of Business \& Industrial Marketing, 29(6): 499-513.

Vang, J. and Zellner, C. (2005). Introduction: Innovation in Services, Industry and Innovation, 12 (2): $147-152$

Wan, D., Ong, H.C. and Francis, L. (2005). Determinants of Firm Innovation in Singapore, Technovation, 25 (3): 261-268. 
Wang, G. and Miao, C.F. (2015). Effects of Sales Force Market Orientation on Creativity, Innovation Implementation, and Sales Performance, Journal of Business Research, 68:2374-2382.

Zhou, K.Z., Yim, Bennett, K.C. and Tse, K.D. (2005). The Effects of Strategic Management Orientations on Technology- and Market- Based Breakthrough Innovations, Journal of Marketing, 69 (2): 40-60.

Zhou, K.Z., Gao, Y.G., Yang Z. and Zhou, N. (2005). Developing Strategic Orientation in China: Antecedents and Consequences of Market and Innovation Orientations, Journal of Business Research, 58 (8): 1049- 1058.

Zhou, K.Z. and Li, B.C. (2010). How Strategic Orientations Influence the Building of Dynamic Capability in Emerging Economies, Journal of Business Research, 63 (3): 224-231. 